\title{
Urban Crime and Pattern Conceptions: Departuring from Spatiality
}

\author{
Hesam Kamalipour, ${ }^{1,}$, Gholamhossein Memarian', Mohsen Faizi1 \\ ${ }^{1}$ Department of Architecture, School of Architecture and Environmental Design, Iran University of Science and \\ Technology, Tehran, Iran \\ ${ }^{2}$ Department of Architecture, Saba Faculty of Art and Architecture, Shahid Bahonar University of Kerman, \\ Kerman, Iran \\ Email: hkamalipour@iust.ac.ir
}

Received 12 April 2014; revised 16 May 2014; accepted 23 May 2014

Copyright @ 2014 by authors and Scientific Research Publishing Inc.

This work is licensed under the Creative Commons Attribution International License (CC BY).

http://creativecommons.org/licenses/by/4.0/

\begin{abstract}
Various conceptions of pattern from biology, computer science, and mathematics to environmental design, psychology, and sociology give rise to the multiplicity of definitions, descriptions, applications, scales, and common features of spatial patterns in urban environments. Considering the complex relations between spatiality and sociality in place theory, the study tends to explore a growing body of knowledge in conceptions of urban crime and pattern. Placing the investigations of urban crime in relation to sociality and spatiality, the paper advocates for departuring from spatiality that is the common ground between urban crime and pattern conceptions. Hence, dismissing both deterministic and free-will approaches to environmental design and addressing the urban crime as a complex city problem, the study argues that adopting a kind of spatial knowledge and possibilistic approach is critical for both understanding and transforming the city in order to investigate the issue of urban crime in relation to spatial patterns.
\end{abstract}

\section{Keywords}

Urban Crime, Pattern, Crime Prevention through Environmental Design, Fear of Crime, Pattern Language, Spatiality

\section{Introduction}

The idea of pattern has been largely articulated in various approaches to evolutionary transformations in generative processes in science and nature. Within the past decade, different scholars and academic trends have adopted various ranges of pattern descriptions, definitions, and articulations in design and urban studies in order to 
provide a basis for understanding urban transformations, evolution processes, and morphological attributes of the city. Besides, different studies of urban crime have adopted various conceptions of crime from being merely a kind of social anomie to a kind of spatial disorder. Hence, diverse articulations of urban crime have led to different propositions of crime as a social, perceptual, and spatial phenomenon. Moreover, a review of literature indicates that criminology, environmental design, sociology, and environmental psychology are closely involved with the issue of crime in the city with relatively difference perspectives. However, these major academic disciplines tend to address and appropriate the complexity of problem with their own articulations and preconceptions of crime. Thus, the complex relations between spatiality and sociality are likely to be contested and challenged whenever the various approaches to urban crime tend to reduce the spatial-social relations of the problem. In this way, the paper includes two interrelated study of urban crime in terms of crime preventions through environmental design and fear of crime and conceptions of pattern and pattern languages. Furthermore, referring to the complexity of urban crime as one of the critical problems of the cities worldwide, the study addresses the relations between conceptions of urban crime, pattern, and pattern languages concerning the spatiality paradigm and sociality-spatiality relations.

\section{Conceptions of Urban Crime}

\subsection{Urban Crime and Crime Prevention}

Being referred to as an anomie that includes victim, offender, and situation [1], urban crime has significant economic impacts on society [2]. Moreover, crime is critically related to public health [3], sustainability [4]-[7], and place attachment [8] [9]. Crime prevention aims for decreasing and discouraging crime and fear of crime [10] in order to mitigate the possible forthcoming problems of new practices of designs [11]. Crime prevention through environmental design (CPTED) focuses on effective implementation of the built environment and design interventions in order to contribute to improve the quality of life, discourage the fear of crime (FOC), and decrease the crime rate [12]. Since the psychobiological and environmental impacts on behavior have been largely ignored in most of the studies on crime prevention [13], the idea of crime prevention can be rooted back to Jeffery [14] as it is firmly related to internal physical organism and external physical environment [15]. Crime prevention tends to identify and modify the social and environmental conditions in which specific opportunities mediate the possible occurrence of crime [16]. Moreover, while different conceptions of urban crime in sociology, psychology, and criminology have generally focused on socio-economic status, demographic profiling, and socio-cultural context of the city, the early environmental studies of urban crime were relatively preoccupied with deterministic articulations of crime in which sociality and behavioral patterns have been supposed to be entirely determined by spatiality and the built environment.

While the early trends and propositions in crime prevention through environmental design [17]-[19] have relatively adopt a deterministic conception of urban crime, further articulations of crime from 1980s as crime pattern theory [20]-[22], situational crime prevention [23] [24], rational choice and opportunity [25] [26], and routine activity [27] [28] have moderately adopted a possibilistic approach to urban crime. Thus, the first and second generations of crime prevention through environmental design are distinguishable from each other in terms of their underlying propositions towards the relations between human and built environment. In this way, while the first-generation studies of urban crime have generally advocated for a deterministic conception of crime in relation to the built environment, the second-generation studies of urban crime have relatively adopted a possibilistic approach towards the relations between crime and built environment. Whilst factors of the first generation are territoriality, access control, surveillance, image and maintenance, target hardening, and support activity, the second generation addresses socio-economic and demographic profiling, risk assessment, and community participation [2] [29]. Meanwhile, it has been denoted that the criteria of both first and second generations of crime prevention through environmental design have vague boundaries and poor spatial and diagrammatic representations [30] [31]. In other words, the proposed factors are not necessarily distinguishable in meaning, spatial structure, and physical representation.

\subsection{Urban Crime and Fear of Crime}

Fear of crime (FOC) has been largely ignored in the statistics of crime and police documentation of the reported crime occurrence [32]. Being addressed as a particular field of study in criminology [33] [34], fear of crime in- 
dicates the anxiety towards the possible incidence of crime and the predictors that are closely related to crime by individuals [35]. Recent studies on the relations between fear of crime and victimization denote that there might not be essentially a direct relationship between victimization and fear of crime [36] [37]. Meanwhile, fear of crime and perceptual dimension of urban crime are different across age and time [38] [39]. Furthermore, it has been largely argued that mass media can also manipulate the fear of crime [40]-[43]. However, most of the studies on fear of crime have generally reduced the complex relations between the perceptual aspect of urban crime and the built environment.

\section{Conceptions of Pattern}

\subsection{Pattern and Abstract-Concrete Relations}

Pattern is likely to be considered as a solution to an existing problem in a given context [44] [45]. In other words, pattern is concerned with the interrelations between context, forces, and spatial structures [46]. However, patterns are naturally multidisciplinary [47] and structurally generative. Thus, patterns tend to diagnose and improve the existing condition by providing possible solutions for the problems [48]. Meanwhile, patterns should be in relation with an extensive range of the other patterns [48]. A pattern is likely to address and explore a repetitive problem in the built environment [49]. In this way, pattern as a wholeness [48] conveys DNA in living structures [50]. Thus, being placed between material and energy [51], a pattern tends to categorize and classify [52]. In other words, patterns are related to a combination of similar properties and features [53] and practical theories are likely to claim for predicting the future by generalizing patterns [54]. While patterns are neither objective nor subjective, they cannot be defined as merely abstract or concrete (Figure 1). Therefore, patterns are likely to be conceptualized between subjective-objective and abstract-concrete relations.

Patterns are extensively broad while forms and shapes are relatively limited [55]. In fact, patterns change through evolutionary processes [56]. Thus, reducing patterns to physical conditions, forms, and shapes ignores the process through which a pattern might change, transform, and evolve [51]. Moreover, processes are working through patterns [57] as the main idea [58]. It has been argued that patterns are likely to be repeatedly practiced regardless of technological and economic issues [59]. Meanwhile, perception of patterns is a mental process [60]. Researches have already indicated that kinds of repetitive patterns are pleasant for the mind [61]. In this way, complex patterns tend to increase pleasure [62]. Moreover, the process of pattern recognition, as one of the fundamental skills of the human being for survival [63], will be possible whenever the perceived pattern and mental schema are in consistency [64]. Thus, pattern recognition as a coherent whole is closely related to the perception of the real world [65]. It has been denoted that the key tool for extracting patterns is an explorative observation [63] [66]. Furthermore, there is a combinational approach to pattern theory that gives rise to the consideration of global and local structures [67]. Hence, while implementation of patterns is related to transcendence [68], patterns include an extensive range of values that are relatively hard to express [69].

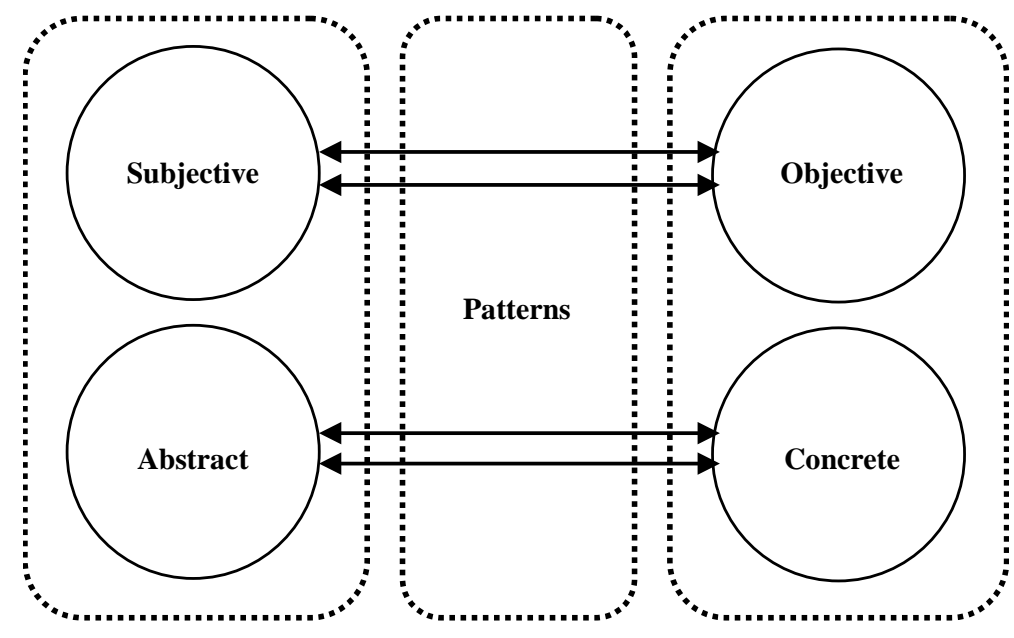

Figure 1. Patterns in between subjective-objective and abstract-concrete relations. 


\subsection{Patterns and Practices of Design}

Patterns have been adopted in design process as a practical guidance [70], a diagram or an abstract [71], and a tool for describing and constructing [72]. Thus, patterns are a kind of abstract mental conceptions [73] from objective forms that are likely to be repetitive in specific contexts [74]. In other words, patterns are a kind of descriptive expression of different relations of a phenomenon that is adapted to the context [75]. In this way, a design pattern captures, defines, and specifies the key features of a design structure and made them applicable for further possible implementations [76]. However, a design pattern is reliant on its own condition, functionality, and applicability [77]. That is why a pattern is more concerned with the problem itself rather than solution [78]. It has been argued that patterns are closely related to design as an expression of identity [79]. Furthermore, rather than capturing the dynamic and stable structures of repetitive solutions in a particular context [80], patterns are likely to initiate a balance between various design forces [81]. Meanwhile, in relation with linguistic patterns, shape grammars are able to contribute to the generation and development of different design languages [78].

The concept of pattern has been largely adopted in architecture, urban design [82], planning, landscape [83], and design practices in the last decades with different articulations. Similarly, pattern has been referred to as a kind of configuration [84], fundamental properties of a spatial design [50], a kind of order [85], repetitive solution [86], systems archetypes and generic structures [87], and a perceptual structure containing model, form, and design [88]. However, long before mathematicians explored the patterns, artists have had a sophisticated understanding of the generic principles for developing patterns [89]. Meanwhile, it has been noted that patterns can be interpreted from biology and implemented in architecture [90]. Thus, a pattern as a reasonable response to needs is actually able to encourage life in different systems and environments [48]. Furthermore, It has been argued that the origin of patterns as architectural solutions and design-level suggestions can be traced back to vernacular settlements and traditional architecture [91]-[96] in which patterns are likely to generate, evolve, and transform through a combinational process of discovery and invention.

\subsection{Patterns and Pattern Languages}

Criticizing the process of housing production [97] and extracting contextual and structural patterns from traditional and vernacular settlements, Christopher Alexander advocates for generating "a pattern language”, as a kind of network-like spatial and diagrammatic knowledge, in order to consider the real needs and behaviors of the inhabitants in the process and practices of participatory and consensus design [98]-[100]. Consequently, these works have had considerable impacts on the formation of "space syntax" approach [101] [102] in architecture and urban design [50]. In this way, it has been argued that pattern is a kind of natural "rule" that gives rise to the relations between a problem and a solution in a context (Figure 2) in order to contribute to the process of possible generation of living structures [46] [103]. In fact, a pattern is likely to emerge in different shapes and types [46].

Pattern languages as systems contain various patterns and connection networks [104] in different scales [86]. In other words, a pattern language can be conceptualized as a network of patterns [105] including a system of connected patterns [45]. Pattern languages are generally based on previous experiences [91], the real needs, and desires of the ordinary people rather than elitist visions of the professionals. Moreover, it has been noted that the

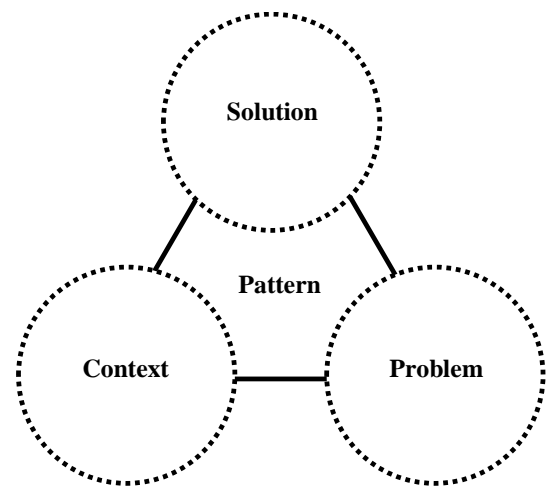

Figure 2. A model of pattern based on Alexander [46] in relation to problem, solution, and context. 
generation and formation of a living environment is highly dependent on dwellers and inhabitants rather than architects and designers [106]. Thus, pattern languages are coherent wholes consist of the interrelated patterns [107]. Generating a system [44], a pattern language tends to address the fundamental challenges of architectureexplicitly [48]. Meanwhile, implantation of spatial patterns and pattern languages can contribute to the process of group work and collaboration [108] [109] and facilitate the practices of multidisciplinary design [48]. In this way, a pattern language includes a structure of connection network [98] that might contribute to the generation of wholeness if it would be morphologically and functionally perfect [46]. Meanwhile, this network is not a hierarchic structure that has been pre-imposed by a tree-like thought [110]. Thus, pattern languages can holistically [48] contribute to the generation of complex systems. Furthermore, pattern languages can be evaluated based on their internal and external validity [111].

\section{Urban Crime and Patterns: A Common Ground}

Urban crime has largely been addressed with different approaches to the conception of crime and its main initiatives. However, the growing body of knowledge in the studies of urban crime refers to the social and spatial aspects of the problem in the cities worldwide. While different approaches to the issue of crime can be categorized in two broad ranges of sociality and spatiality, it is possible to denote that urban crime cannot be thoroughly explored in the absence of either social constructs or spatial features. Besides, considering the relations between sociality and spatiality in the city, it has been critically argued that the practices of design and interventions in the built environment need to be based on "design-level" theories in which the spatiality is likely to be considered as a departure point [112]. However, it does not necessarily mean that the spatial interventions can be simply reduced to the provision and implementation of some generic, typical, and taken-for-granted guidelines through which most of the social aspects of crime are deterministically reduced, arbitrarily dismissed, and explicitly or implicitly ignored without context sensitivity.

On the other hand, while both determinism and free-will approaches in environmental design cannot effectively address the multiplicity of the city problems, it is not reasonably possible to advocate for adopting a kind of narrow-minded determinism in which designers are generally considered as the elites who have an unlimited power to determine the social outcomes of the spatial modifications. As it has been insightfully argued, city problems are structurally a kind of "organized complexity" [18] and "semi-lattice" [110] that cannot simply be treated through adopting a rigidly hierarchic "tree-like" way of thinking. However, some of the spatial patterns outlined in Alexander, et al. [98] have a deterministic approach and some of them cannot be implemented together in a same context. Thus, there is a possibilistic relation between urban crime and built environment [113]. In this way, adopting probabilistic and possibilistic approaches rather than deterministic and free-will ones (Figure 3), patterns and pattern languages are closely related to the process of decision-making, design-level

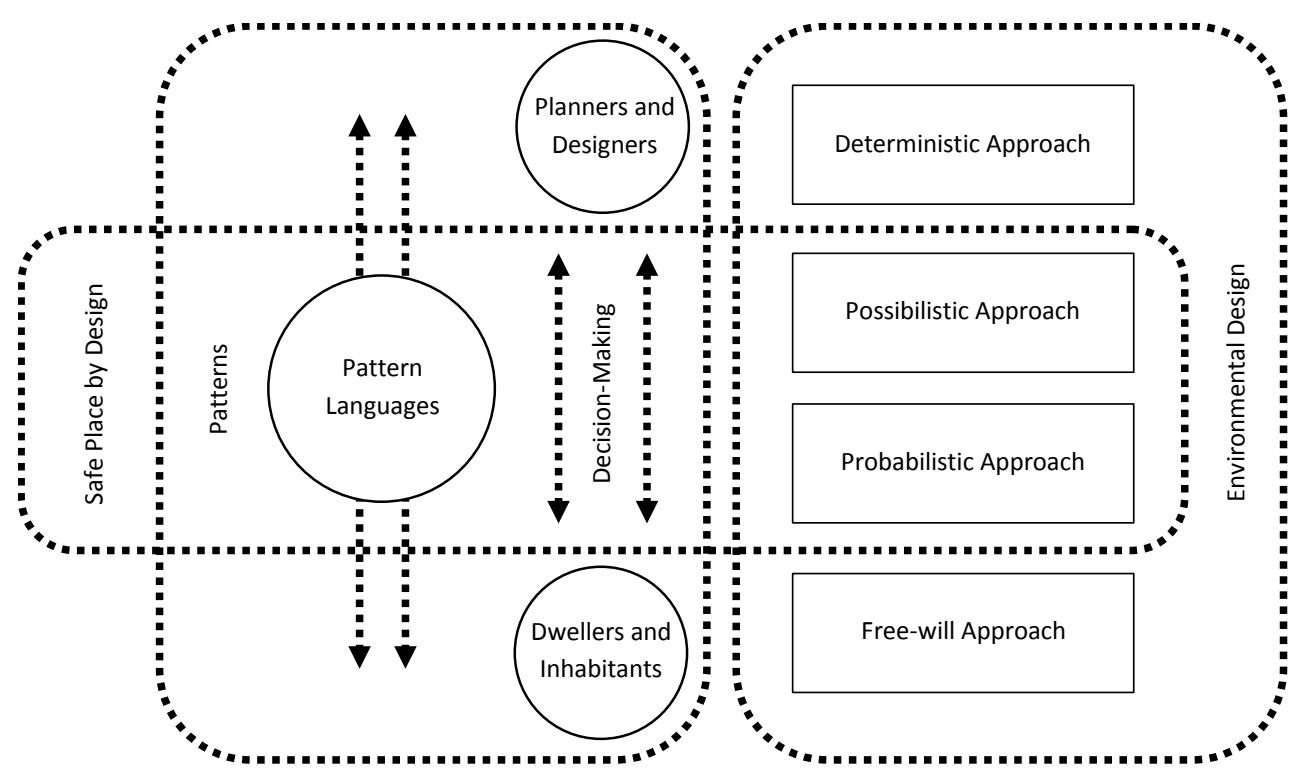

Figure 3. Urban crime and patterns in relation to Lang [114] approaches to environmental design. 
modifications, and evidence-based interventions in the built environments.

Furthermore, the issue of urban crime is multidimensional. That is why any desire for a safe place incorporates functional, morphological, perceptual, and social dimensions of the urban environments. Moreover, it has been denoted that the criteria of crime prevention through environmental design (CPTED) cannot simply be limited to the physicality of the urban environments because almost all of them encompass various dimensions of urban design [115]. Meanwhile, the complexity of city problems gives rise to the need for conducting holistic, multi-scalar, multidimensional, and multidisciplinary studies of urban crime in relation to the built environment [116]. Hence, the need for "design-level” theories in relation to spatiality and sociality [112] advocates for the analysis of spatial patterns in urban design level [117] [118] within the spatiality paradigm in which spatiality is the departure point [112] and the relations between urban crime and built environment is neither deterministic nor free-will. In the same vein, the study denotes that the spatial patterns intended to mitigate the possibility of urban crime in public places and urban spaces would be better to contribute effectively to urbanity in general and urban life in particular. Otherwise, these patterns might lead to segregation and social exclusion in urban environments. Meanwhile, since both observation and reflection are actively involved in the generation process of patterns, it should be noted that relying merely on invention in the absence of discovery and explanatory observation might bring the unintended consequences of imposing abstract and subjective conceptions of pattern as a kind of determinism to the real practices of everyday life in the city.

\section{References}

[1] Felson, M. (1994) Crime and Everyday Life: Insights and Implications for Society. Pine Forge Press, Thousand Oaks.

[2] Glasson, J. and Cozens, P. (2011) Making Communities Safer from Crime: An Undervalued Element in Impact Assessment. Environmental Impact Assessment Review, 31, 25-35. http://dx.doi.org/10.1016/j.eiar.2010.03.007

[3] Cozens, P. (2007) Public Health and the Potential Benefits of Crime Prevention through Environmental Design. New South Wales Public Health Bulletin, 18, 232-237. http://dx.doi.org/10.1071/NB07025

[4] Armitage, R. and Gamman, L. (2009) Sustainability via Security: A New Look. Built Environment, 35, $297-301$. http://dx.doi.org/10.2148/benv.35.3.297

[5] Du Plessis, C. (1999) The Links between Crime Prevention and Sustainable Development. Open House International, 24, 33-40.

[6] Dewberry, E. (2003) Designing out Crime: Insights from Eco-Design. Security Journal, 16, 51-62. http://dx.doi.org/10.1057/palgrave.sj.8340125

[7] Cozens, P. (2002) Sustainable Urban Development and Crime Prevention through Environmental Design for the British City. Towards an Effective Urban Environmentalism for the 21st Century. Cities, 19, 129-137. http://dx.doi.org/10.1016/S0264-2751(02)00008-2

[8] Scannell, L. and Gifford, R. (2010) Defining Place Attachment: A Tripartite Organizing Framework. Journal of Environmental Psychology, 30, 1-10. http://dx.doi.org/10.1016/j.jenvp.2009.09.006

[9] Kamalipour, H., Yeganeh Jeddi, A. and Alalhesabi, M. (2012) Predictors of Place Attachment in Urban Residential Environments: A Residential Complex Case Study. Procedia-Social and Behavioral Sciences, 35, 459-467. http://dx.doi.org/10.1016/j.sbspro.2012.02.111

[10] Hedayati Marzbali, M., Abdullah, A., Razak, N.A. and Maghsoodi Tilaki, M.J. (2012) Validating Crime Prevention through Environmental Design Construct through Checklist Using Structural Equation Modelling. International Journal of Law, Crime and Justice, 40, 82-99. http://dx.doi.org/10.1016/j.ijlcj.2011.08.005

[11] Clarke, R.V. (2009) Situational Crime Prevention: Theoretical Background and Current Practice. In: Krohn, M.D., Lizotte, A.J. and Hall, G.P., Eds., Handbook on Crime and Deviance, Springer, Dordrecht, New York, 259-276. http://dx.doi.org/10.1007/978-1-4419-0245-0_14

[12] Crowe, T.D. (2000) Crime Prevention through Environmental Design: Applications of Architectural Design and Space Management Concepts. 2nd Edition, Butterworth-Heinemann, Oxford.

[13] Jeffery, C.R. (1996) Mental Health and Crime Prevention: A Public Health Model. Paper presented at the International Crime Prevention Practitioners Conference, Vancouver.

[14] Jeffery, C.R. (1971) Crime Prevention through Environmental Design. Sage Publications, Beverly Hills Calif.

[15] Robinson, M.B. (1996) The Theoretical Development of CPTED: 25 Years of Responses to C. Ray Jeffery. In: Laufer, W.S. and Adler, F., Eds., The Criminology of Criminal Law (Advances in Criminological Theory) (Vol. 8). Transaction Publishers, New Brunswick, 427-462. 
[16] Brantingham, P.J. and Faust, F.L. (1976) A Conceptual Model of Crime Prevention. Crime and Delinquency, 22, 284295. http://dx.doi.org/10.1177/001112877602200302

[17] Wood, E. (1961) Housing Design: A Social Theory. Citizens’ Housing and Planning Council of New York, New York.

[18] Jacobs, J. (1961) The Death and Life of Great American Cities. Random House, New York.

[19] Newman, O. (1972) Defensible Space: Crime Prevention through Urban Design. Macmillan, New York.

[20] Brantingham, P.L. and Brantingham, P.J. (1993) Nodes, Paths and Edges: Considerations on the Complexity of Crime and the Physical Environment. Journal of Environmental Psychology, 13, 3-28. http://dx.doi.org/10.1016/S0272-4944(05)80212-9

[21] Brantingham, P.J. and Brantingham, P.L. (1984) Patterns in Crime. MacMillan, New York.

[22] Brantingham, P.J. and Brantingham, P.L. (1981) Environmental Criminology. Sage Publications, Beverly Hills.

[23] Clarke, R.V. (1980) Situational Crime Prevention: Theory and Practice. Harrow and Heston, Albany.

[24] Clarke, R.V. and Cornish, D.B. (1985) Modeling offenders’ Decisions: A Framework for Research and Policy. In: Tonry, M. and Morris, N., Eds., Crime and Justice: An Annual Review of Research, Vol. 6, University of Chicago Press, Chicago, 147-185.

[25] Fattah, E.A. (1993) The Rational Choice/Opportunity Perspectives as a Vehicle for Integrating Criminological and Victimological Theories. In: Clarke, R.V. and Felson, M., Eds., Routine Activity and Rational Choice: Advances in Criminological Theory, Vol. 5, Transaction Publishers, New Brunswick, 225-258.

[26] Cornish, D. and Clarke, R.V. (1986) The Reasoning Criminal: Rational Choice Perspectives on Offending. SpringerVerlag, The Hague.

[27] Cohen, L.E. and Felson, M. (1979) Social Change and Crime Rate Trends: A Routine Activity Approach. American Sociological Review, 44, 588-608. http://dx.doi.org/10.2307/2094589

[28] Maxfield, M.G. (1987) Lifestyle and Routine Activity Theories of Crime: Empirical Studies of Victimization, Delinquency, and Offender Decision-Making. Journal of Quantitative Criminology, 3, 275-282. http://dx.doi.org/10.1007/BF01066831

[29] Cozens, P., Saville, G. and Hillier, D. (2005) Crime Prevention through Environmental Design (CPTED): A Review and Modern Bibliography. Property Management, 23, 328-356. http://dx.doi.org/10.1108/02637470510631483

[30] Ekblom, P. (2011) Deconstructing CPTED... and Reconstructing It for Practice, Knowledge Management and Research. European Journal on Criminal Policy and Research, 17, 7-28. http://dx.doi.org/10.1007/s10610-010-9132-9

[31] Gamman, L. and Pascoe, T. (2004) Seeing Is Believing: Notes towards a Visual Methodology and Manifesto for Crime Prevention through Environmental Design. Crime Prevention and Community Safety Journal, 6, 9-18. http://dx.doi.org/10.1057/palgrave.cpcs.8140198

[32] Cozens, P. (2008) Crime Prevention through Environmental Design (CPTED) in Western Australia: Planning for Sustainable Urban Futures. International Journal of Sustainable Development and Planning, 3, 272-292. http://dx.doi.org/10.2495/SDP-V3-N3-272-292

[33] Lab, S.P. (2010) Crime Prevention: Approaches, Practices, and Evaluations. 7th Edition, Lexis Nexis Matthew Bender, New Providence.

[34] Lee, M. (2007) Inventing Fear of Crime: Criminology and the Politics of Anxiety. Willan Publishing, Cullompton, Devon.

[35] Ferraro, K.F. (1995) Fear of Crime: Interpreting Victimization Risk. State University of New York Press, New York.

[36] Minnery, J.R. and Lim, B. (2005) Measuring Crime Prevention through Environmental Design. Journal of Architectural and Planning Research, 22, 330-341.

[37] Marzbali, M.H., Abdullah, A., Razak, N.A. and Maghsoodi Tilaki, M.J. (2012) The Influence of Crime Prevention through Environmental Design on Victimisation and Fear of Crime. Journal of Environmental Psychology, 32, 79-88. http://dx.doi.org/10.1016/j.jenvp.2011.12.005

[38] Garofalo, J. (1979) Victimization and the Fear of Crime. Journal of Research in Crime and Delinquency, 16 , 80-97. http://dx.doi.org/10.1177/002242787901600107

[39] Schneider, R.H. and Kitchen, T. (2002) Planning For Crime Prevention: A Transatlantic Perspective. Routledge, London.

[40] Chadee, D. and Ditton, J. (2005) Fear of Crime and the Media: Assessing the Lack of Relationship. Crime, Media, Culture, 1, 322-332. http://dx.doi.org/10.1177/1741659005057644

[41] Colquhoun, I. (2004) Design out Crime: Creating Safe and Sustainable Communities. Architectural Press, Oxford, Burlington.

[42] Moon, D., Walker, A., Murphy, R., Flatley, J., Parfrement-Hopkins, J. and Hall, P. (2009) Perceptions of Crime and 
Anti-Social Behaviour: Findings from the 2008/09 British Crime Survey. Home Office, London.

[43] Ditton, J., Chadee, D., Farrall, S., Gilchrist, E. and Bannister, J. (2004) From Imitation to Intimidation. British Journal of Criminology, 44, 595-610. http://dx.doi.org/10.1093/bjc/azh028

[44] Coplien, J. (1996) Software Patterns. SIGS Books and Multimedia, New York.

[45] Salustri, F.A. (2001) Using Design Patterns to Promote Multidisciplinary Design. Proceedings of CSME International Conference on Multi-Displinary Design Engineering, Montreal, 21-22 November 2001.

[46] Alexander, C. (1979) The Timeless Way of Building. Oxford University Press, New York.

[47] Coad, P. (1992) Object-Oriented Patterns. Communications of the ACM, 35, 152-159. http://dx.doi.org/10.1145/130994.131006

[48] Schuler, D. (2008) Liberating Voices: A Pattern Language for Communication Revolution. MIT Press, Cambridge.

[49] Inam, A. (2008) Meaningful Urban Design: Teleological/Catalytic/Relevant. In: Kelbaugh, D. and McCullough, K.K., Eds., Writing Urbanism: A Design Reader, ACSA Architectural Education Series, Routledge, London, 14-23.

[50] Garcia, M. (2009) Prologue for a History, Theory and Future of Patterns of Architecture and Spatial Design. Architectural Design, 79, 6-17. http://dx.doi.org/10.1002/ad.974

[51] Hensel, M. and Menges, A. (2009) Patterns in Performance-Orientated Design: An Approach towards Pattern Recognition, Generation and Instrumentalisation. Architectural Design, 79, 88-93. http://dx.doi.org/10.1002/ad.984

[52] Berne, E. (1964) Games People Play: The Psychology of Human Relationships. Grove Press, New York.

[53] Eckert, C. and Clarkson, J. (2005) The Reality of Design. In: Clarkson, J. and Eckert, C., Eds., Design Process Improvement: A Review of Current Practice, Springer, London, 1-29. http://dx.doi.org/10.1007/978-1-84628-061-0_1

[54] Krippendorff, K. (2007) Design Research, an Oxymoron? In: Michel, R., Ed., Design Research Now: Essays and Selected Projects, De Gruyter, Berlin, Boston, 67-80. http://dx.doi.org/10.1007/978-3-7643-8472-2_5

[55] Ball, P. (2009) Nature’s Patterns: Shapes, Vol. 1. Oxford University Press, Oxford, New York.

[56] Nijhout, H.F. (1997) Pattern and Process. In: Nijhout, H.F., Nadel, L. and Stein, D.L., Eds., Pattern Formation in the Physical and Biological Sciences, Vol. 5, Addison-Wesley, Reading, 269-297.

[57] Garcia, M. (2009) Reductive Engineering Patterns: An Interview with Hanif Kara. Architectural Design, 79, 66-73. http://dx.doi.org/10.1002/ad.981

[58] McTighe, J. and Wiggins, G.P. (1999) Understanding by Design Handbook. Association for Supervision and Curriculum Development, Alexandria.

[59] Bonsiepe, G. (2007) The Uneasy Relationship between Design and Design Research. In: Michel, R., Ed., Design Research Now: Essays and Selected Projects, De Gruyter, Berlin, Boston, 25-39. http://dx.doi.org/10.1007/978-3-7643-8472-2_2

[60] Ball, P. (1999) The Self-Made Tapestry: Pattern Formation in Nature. Oxford University Press, Oxford.

[61] Sternberg, E.M. (2009) Healing Spaces: The Science of Place and Well-Being. Belknap Press of Harvard University Press, Cambridge.

[62] Klinger, A. and Salingaros, N.A. (2000) A Pattern Measure. Environment and Planning B: Planning and Design, 27, 537-547. http://dx.doi.org/10.1068/b2676

[63] Blesser, B. and Salter, L.R. (2007) Spaces Speak, Are You Listening? Experiencing Aural Architecture. MIT Press, Cambridge.

[64] Ingold, T. (2000) The Perception of the Environment: Essays on Livelihood, Dwelling and Skill. Routledge, New York. http://dx.doi.org/10.4324/9780203466025

[65] Tarr, M.J. (2000) Pattern Recognition. In: Kazdin, A.E., Ed., Encyclopedia of Psychology, Vol. 6, American Psychological Association, Washington DC, 66-71.

[66] Golledge, R.G. (1991) Cognition of Physical and Built Environments. In: Gärling, T. and Evans, G.W., Eds., Environment, Cognition, and Action: An Integrated Approach, Oxford University Press, New York, 35-62.

[67] Grenander, U. and Miller, M.I. (2007) Pattern Theory: From Representation to Inference. Oxford University Press, New York.

[68] Kurzweil, R. (2005) The Singularity Is Near: When Humans Transcend Biology. Viking, New York.

[69] Kaplan, R. (1991) Environmental Description and Prediction: A Conceptual Analysis. In: Gärling, T. and Evans, G.W., Eds., Environment, Cognition, and Action: An Integrated Approach, Oxford University Press, New York, 19-34.

[70] Weinthal, L. (2008) Pattern. In: Erlhoff, M. and Marshall, T., Eds., Design Dictionary: Perspectives on Design Terminology, Birkhäuser Verlag, Basel, 293-294.

[71] Davies, N. and Jokiniemi, E. (2008) Dictionary of Architecture and Building Construction. Elsevier/Architectural Press, 
Oxford.

[72] Spyropoulos, T. (2009) Evolving Patterns: Correlated Systems of Interaction. Architectural Design, 79, 82-87. http://dx.doi.org/10.1002/ad.983

[73] Harrison, L.G. (2011) The Shaping of Life: The Generation of Biological Pattern. Cambridge University Press, Cambridge.

[74] Riehle, D. and Züllighoven, H. (1996) Understanding and Using Patterns in Software Development. Theory and Practice of Object Systems, 2, 3-13.

[75] Grabow, S. (1983) Christopher Alexander: The Search for a New Paradigm in Architecture. Oriel Press, Stocksfield, Boston.

[76] Gamma, E. (1995) Design Patterns: Elements of Reusable Object-Oriented Software. Addison-Wesley, Boston.

[77] Taylor, M. (2009) Relentless Patterns: The Immersive Interior. Architectural Design, 79, 42-47. http://dx.doi.org/10.1002/ad.977

[78] Terzidis, K. (2006) Algorithmic Architecture. 1st Edition, Architectural Press, Amsterdam, Boston.

[79] Rodemann, P.A. (2009) Psychology and Perception of Patterns in Architecture. Architectural Design, 79, $100-107$. http://dx.doi.org/10.1002/ad.986

[80] Coplien, J.O. and Schmidt, D.C. (1995) Pattern Languages of Program Design. Addison-Wesley, Reading.

[81] Weiss, M. (2003) Pattern-Driven Design of Agent Systems: Approach and Case Study. Proceedings of the 15th International Conference on Advanced Information Systems Engineering, Klagenfurt, 16-20 June 2003, 711-723. http://dx.doi.org/10.1007/3-540-45017-3_47

[82] McGrath, B. and Marshall, V. (2009) New Patterns in Urban Design. Architectural Design, 79, 48-53. http://dx.doi.org/10.1002/ad.978

[83] Swaffield, S. (2009) Tracing Change: Patterns in Landscape Architecture. Architectural Design, 79, 54-59. http://dx.doi.org/10.1002/ad.979

[84] Hall, G.M. (1997) The Ingenious Mind of Nature: Deciphering the Patterns of Man, Society, and the Universe. Plenum Press, New York.

[85] Akkach, S. (2005) Cosmology and Architecture in Premodern Islam: An Architectural Reading of Mystical Ideas. State University of New York Press, Albany.

[86] Salingaros, N.A. (2005) Pattern Language and Interactive Design. In: Salingaros, N.A., Coward, L.A., West, B.J. and Bilsen, A., Eds., Principles of Urban Structure, Techne Press, Amsterdam, 211-220.

[87] Senge, P.M. (1990) The Fifth Discipline: The Art and Practice of the Learning Organization. Doubleday/Currency, New York.

[88] Harris, C.M. (2006) Dictionary of Architecture \& Construction. McGraw-Hill, New York.

[89] Pottman, H. (2009) Geometry and New and Future Spatial Patterns. Architectural Design, 79, 60-65. http://dx.doi.org/10.1002/ad.980

[90] Vincent, J. (2009) Biomimetic Patterns in Architectural Design. Architectural Design, 79, 74-81. http://dx.doi.org/10.1002/ad.982

[91] Brawne, M. (2003) Architectural Thought: The Design Process and the Expectant Eye. Architectural Press, Oxford.

[92] Kamalipour, H., Dorrani Arab, A., Soltani, S., Naser Alavi, S. and Mirzaei, E. (2013) Understanding Continuity and Change in the Persian Vernacular Settlements: A Comparative Syntactic Analysis of Urban Public Spaces in a Case Study. Current Urban Studies, 1, 130-138. http://dx.doi.org/10.4236/cus.2013.14014

[93] Kamalipour, H., Memarian, G. and Mousavian, S.M.F. (2012) Exploring the Myth of Four in the Persian Vernacular Architecture. The IASTE 2012: The Myth or Tradition, University of Oregon, Portland, Oregon, 4-7 October 2012.

[94] Kamalipour, H., Memarian, G., Faizi, M. and Mousavian, F. (2012) Formal Classification and Spatial Configuration in Vernacular Housing: A Comparative Study on the Zoning of the Reception Area in Traditional Houses of Kerman Province. Journal of Housing and Rural Environment, 31, 3-16.

[95] Memarian, G., Hashemi Toghroljerdi, S.M. and Kamalipour, H. (2012) The Impact of Religious and Behavioral Patterns on the Order of Vernacular Settlements: A Comparative Case Study. International Journal of Architecture Engineering \& Urban Planning, 22, 91-99.

[96] Memarian, G., Hashemi Toghroljerdi, S.M. and Kamalipour, H. (2010) The Impact of Religious Culture on Organization of Houses: Comparative Study of Houses in Islamic, Zoroastrian, and Jewish Districts of Kerman. Iranian Journal of Cultural Research, 3, 1-25.

[97] Alexander, C., Davis, H., Martinez, J. and Corner, D. (1985) The Production of Houses. Oxford University Press, New 
York.

[98] Alexander, C., Ishikawa, S. and Silverstein, M. (1977) A Pattern Language: Towns, Buildings, Construction. Oxford University Press, New York.

[99] Alexander, C., Ishikawa, S. and Silverstein, M. (1968) A Pattern Language Which Generates Multi-Service Centers. Center for Environmental Structure, Berkeley.

[100] Alexander, C. (1970) Houses Generated by Patterns. Center for Environmental Structure, Berkeley.

[101] Hillier, B. (1996) Space Is the Machine: A Configurational Theory of Architecture. Cambridge University Press, Cambridge, New York.

[102] Hillier, B. and Hanson, J. (1984) The Social Logic of Space. Cambridge University Press, Cambridge, New York. http://dx.doi.org/10.1017/CBO9780511597237

[103] Alexander, C. (2002) The Process of Creating Life: An Essay on the Art of Building and the Nature of the Universe. Center for Environmental Structure, Berkeley.

[104] Kimble, C. and Selby, W. (2000) An Interdisciplinary Study of Information Systems: Christopher Alexander and IS Failure. Proceedings of 5th UKAIS Conference, Cardiff, 26-28 April 2000, McGraw Hill.

[105] O’Callaghan, A. (2000) Patterns for Architectural Praxis. Proceedings of Euro PLoP, Irsee.

[106] Westermann, C. (2006) Who Plays the Nightingale? In: Ascott, R., Ed., Engineering Nature: Art \& Consciousness in the Post-Biological Era, Intellect, Bristol, Portland, 189-193.

[107] Appleton, B. (1997) Patterns and Software: Essential Concepts and Terminology. Object Magazine Online, 3, $20-25$.

[108] Kamalipour, H., Mansouri Kermani, Z. and Houshmandipanah, E. (2014) Collaborative Design Studio on Trial: A Conceptual Framework in Practice. Current Urban Studies, 2, 1-12. http://dx.doi.org/10.4236/cus.2014.21001

[109] Kamalipour, H. and Biglari, S. (2013) Implementing Patterns and Pattern Languages in Collaborative Design Pedagogy: A Case Study in Architectural Education. The IESC 2013: The Young Teachers of the Future Discuss Teaching Profession at Maltepe University, Istanbul, 2-3 May 2013.

[110] Alexander, C. (1964) A City Is Not a Tree. Architectural Forum, 122, 58-61.

[111] Salingaros, N.A. (2000) The Structure of Pattern Languages. Architectural Research Quarterly, 4, 149-162. http://dx.doi.org/10.1017/S1359135500002591

[112] Hillier, B. (2008) Space and Spatiality: What the Built Environment Needs from Social Theory. Building Research \& Information, 36, 216-230. http://dx.doi.org/10.1080/09613210801928073

[113] Biddulph, M. (2007) Introduction to Residential Layout. Butterworth-Heinemann, Oxford, Burlington.

[114] Lang, J.T. (1987) Creating Architectural Theory: The Role of the Behavioral Sciences in Environmental Design. Van Nostrand Reinhold Co., New York.

[115] Kamalipour, H., Memarian, G., Faizi, M. and Mousavian, S.M.F. (2013) Evaluating CPTED Measures in Historical Urban Public Places: A Syntactic Analysis of a Case Study. Journal of Basic and Applied Scientific Research, 3, 795805.

[116] Kamalipour, H., Faizi, M. and Memarian, G. (2014) Safe Place by Design: Urban Crime in Relation to Spatiality and Sociality. Current Urban Studies, 2, in Press.

[117] Hillier, B. (2004) Can Streets Be Made Safe? Urban Design International, 9, 31-45. http://dx.doi.org/10.1057/palgrave.udi.9000079

[118] Hillier, B. and Shu, S. (2000) Crime and Urban Layout: The Need for Evidence. In: Ballintyne, S., Pease, K. and McLaren, V., Eds., Secure Foundations: Key Issues in Crime Prevention, Crime Reduction and Community Safety, Institute of Public Policy Research, London, 224-248. 